\title{
DEVLET TEORİSİNDE KUVVETLER AYRILIĞININ DOĞUŞU: LOCKE VE MONTESQUIEU
}

\author{
Dr. Öğr. Üyesi Ayşe ÖZKAN DUVAN*
}

\begin{abstract}
ÖZET
Kuvvetler ayrılığı ilkesi günümüzde demokratik anayasal yönetim anlayışının tartışmasız temel unsuru olarak kabul edilmektedir. İktidarı kullananların yetkilerini sınırlama ihtiyacıyla ortaya çıkan bu ilkenin tarihsel gelişim süreci İlk Çağ’a kadar uzanmaktadır. Ancak modern anlamıla kuvvetler ayrılığ1 anlayışının kökenleri büyük ölçüde İngiliz filozof Locke ve Fransız düşünür Montesquieu'nun çalışmalarına dayanmaktadır. Locke'un yasamayürütme-federatif erkler ayrımı, Montesquieu'da yasama-yürütme-yargı ayrımı formunu kazanmıştır. Bu çalışmada, öncelikle üçlü erkler ayrımının gelişim süreci, düşünürlerin yaklaşımları bakımından ayrı ayrı ele alınmaktadır. Ardından farklı özellikleri bakımından erkler ayrılığı düşüncelerinin analizi yapılmaktadır. Locke, Montesquieu, hatta son bölümde kuvvetler ayrılığının yanlış olduğunu savunan muhaliflerin, Rousseau'nun düşünceleri ele alınmaktadır. Yasamanın üstünlüğü görüşünün öne çıkması nedeniyle erkler arasındaki ilişkiler için öngörülen fren ve denge mekanizmasının ancak devrimler döneminden sonra etkin şekilde uygulama alanı bulduğu öne sürülmektedir.
\end{abstract}

Anahtar Kelimeler: Devlet Teorisi, Kuvvetler Ayrıllğı, Yasama Erki, Yürütme Erki, Yargi Erki, Locke, Montesquieu.

* İstanbul Üniversitesi Hukuk Fakültesi Genel Kamu Hukuku Anabilim Dalı, ayse.duvan@istanbul.edu.tr (Geliş Tarihi: 31.07.2018 - Kabul Tarihi: 23.10.2018) 


\title{
THE EMERGENCE OF DOCTRINE OF THE SEPARATION OF POWERS: LOCKE AND MONTESQUIEU
}

\begin{abstract}
The principle of separation of powers is now regarded as a fundamental element of democratic constitutional governance. The historical development process of this principle, which emerged with the need of limitation of power users, extends to the early ages. But the modern sense of the concept of separation of forces is largely based on the work of the English philosopher Locke and the French thinker Montesquieu. Locke's legislative-executivefederative separation of powers has won the form of legislative-executivejudicial separation in Montesquieu. In this study, the process of development of the division of triad powers is firstly handled separately in terms of the approaches of thinkers. Then, comparative analysis of different features is made. Locke, Montesquieu, and even Rousseau, who argues that the separation of forces is wrong. Finally, it is argued that the mechanism of checks and balances proposed for relations between the powers because of the prominence of parliamentary superiority has only been effectively applied after the period of revolutions.
\end{abstract}

Key Words: State Theory, Separation of Powers, Legislative Power, Executive Power, Judicial Power, Locke, Montesquieu. 


\section{GİRIŞ}

Siyaset teorisinde devlet olarak tanımlanan yapı, bir bütün olarak kabul edilmekle birlikte devlet gücünün kullanılması söz konusu olduğunda bütünlükten söz edilememektedir. İktidarın sınırlanması ihtiyacıyla gelişen erkler ayrımı, devletin yerine getirdiği görevlerin ayrılması olarak anlaşılmaktadır. Devletin bu görevlerinin her biri belirli bir organa verilir ve bu organların yapısal bakımdan göreceği işler onların fonksiyonu olarak biçimlenir. Kuvvetler arasındaki ilişki ve meydana gelen karşlıklı etkileşim, siyasal rejimlerin niteliklerini saptayıcı niteliktedir. Özellikle de yasama erki ile yürütme erki arasındaki ilişki bu anlamda daha belirleyici bir mahiyet arz eder. ${ }^{1}$ Devlet olarak tanımlanan yapının egemen iradesini kullanma şeklini belirlemede çözüm olarak sunulan kuvvetler ayrıllı̆̆ ilkesi, uzun bir süreçte olgunlaşmıştır.

Kuvvetler ayrılı̆̆ düşüncesinin gelişim sürecini, ideal devlet arayışına katkıda bulunan İlk Çağ düşünürlerine kadar götürmek mümkündür. Sürece katkısı bakımından bu dönemin düşünürleri arasında Aristoteles'in çalışmaları ön plana çıkmaktadır. Erdemlilikten hareketle en iyi hükümet fikrini arayan Aristoteles, devletin faaliyetlerini üçe ayırarak her faaliyetin bir organa verilmesi gerektiği düşüncesini ilk kez ortaya atmış; bu düşünceye dayanan güçler ayrımının ilk tasvirini ve tahlilini yapmıştır. ${ }^{2}$ Aristoteles'e göre, en iyi anayasa, iki yanlış yönetim şekli olan oligarşi ile demokrasinin karışımı sonucunda ortaya çıkacak doğru bir yönetim şekli olan bir karma anayasa olacaktır. Böyle bir anayasa Aristoteles tarafından "her devlette bulunan erklerin dağılımının, egemenliğin yerinin ve siyasal toplumun gerçekleştirmeyi amaçladığı hedefin belirlenmesi için benimsenen düzenleniş biçimi” şeklinde tanımlanmıştır. ${ }^{3}$

Üçlü iktidar anlayışını geliştiren Aristoteles, yönetimin üç işlevle sağlanabileceğini savunmuştur. ${ }^{4} \mathrm{Bu}$ işlevler, yasamaya tekabül eden müzakere ma-

1 Tunaya, Tarık Zafer (1980) Siyasal Kurumlar ve Anayasa Hukuku, 4. Bası, İstanbul, İstanbul Üniversitesi Hukuk Fakültesi Yayınları, Fakülteler Matbaası, s. 390.

2 Doehring, Karl (2002) Genel Devlet Kuramı (Genel Kamu Hukuku), Mumcu, Ahmet (Çev.), İstanbul, İnkılap Kitabevi, s. 192; Ağaoğulları, Mehmet Ali (2002) Kral Devletinden İmparatorluğa, 3. Bası, Ankara-İstanbul, İmge Kitabevi, s. 355; Akgül, Mehmet Emin, 'Kuvvetler Ayrılığı İlkesini Dönüşümü ve Günümüz Demokratik Rejimlerindeki Anlamı', Ankara Barosu Dergisi, S: 4, Y: 2010, ss. 79-101, s. 82.

Ăgaoğulları (2002) s. 355.

Aristoteles (2005) Politika, Tunçay, Mete (Çev.), İstanbul, Remzi Kitabevi, s. 132-133; Touchard, Jean (2015) Siyasal Düşünceler Tarihi, Yerguz, İsmail (Çev.), İstanbul, Islık Yayınlar1, s. 61. 
kamı, yürütmeye tekabül eden kumanda makamı ve yargıya tekabül eden adalet makamıdır. ${ }^{5}$ Yasama erki Aristoteles'in düşüncesinde, savaş ve barışa karar verme, anlaşma yapma ve bozma, yasa koyma ve kaldırma, ölüm, sürgün veya mala el koyma cezası verme yetkisiyle donatılmış en üstün güç olarak tasarlanmıştır. Yürütme erki, belirli konularda görüşme yapıp karar alma ve buna ilişkin buyruk verme yetkisiyle donatılmıştır. Aristoteles'in düşüncesinde yarg1 erkine davalara bakma yetkisine sahip olarak daha kısa bir şekilde değinilmiştir. Geliştirdiği bu görüşlerle üç ayrı iktidar alanı ayrımını yapmış olmakla birlikte, Aristoteles'in modern anlamda, erklerin birbirlerini dengeleyip frenledikleri kuvvetler ayrıllğ 1 düşüncesine sahip olmadığ 1 kabul edilmektedir. ${ }^{6}$ Aristoteles'in üçlü erkler ayrımını yapmasındaki amaç, devlet şekillerini daha belirgin şekilde analiz etmek, bunlar arasındaki anayasal farklılıkları daha açık şekilde ortaya koymak ve karakterize etmek olarak anlaşılmıştır. Meclislerin, yöneticilerin ve yargıçların belirlenmesi ve işlevlerinin saptanması, esas alınacak rejim türüne göre değişiklik arz etmektedir. Dolayısıyla söz konusu ayrım, bir gelecek vaat eden ancak kesinlikle bir kuvvetler ayrılığı öğretisi olarak nitelenemeyecek işlevsel bir ayrımdır. ${ }^{7}$ Roma döneminin siyaset kuramcılarından olan Polybios da Yunan düşünürleri tarafından geliştirilen karma anayasa kuramının bir başka temsilcisidir. Polybios, yönetimin bozulmasının önüne geçmek için siyasal gücün, birbirini denetleyebilecek çeşitli kurumlar arasında dağıtılmasını uygun bulmuştur. ${ }^{8}$ Kuşkusuz çağdaş hukuk ve egemenlik teorileri ile İlk Çağ düşünürlerinin geliştirdiği bu yaklaşımlar arasında yakın bir ilişki vardır. ${ }^{9}$

Modern anlamıyla kuvvetler ayrılığı anlayışının kökenleri büyük ölçüde İngiliz filozof John Locke ve Fransız düşünür Baron de Montesquieu'nun çalışmalarına dayanmaktadır. Kavramın oluşmasında ise iki düşünürle birlikte Lord Bolinbroke’un çalışmaları da pay sahibidir. Voltaire'i ve Montesquieu’yu

5 Akipek, İlhan 'Kuvvetler Ayrılığı Nazariyesinin Doğmasında Âmil Olan Fikirler', Ankara Üniversitesi Hukuk Fakültesi Dergisi, C: 9, S: 1, Y: 1952, ss. 167-182, s. 168.

6 Ağaoğulları (2002) s. 356; Akad, Mehmed / Dinçkol, Bihterin Vural / Bulut, Nihat (2014) Genel Kamu Hukuku, 10 Bası, İstanbul, Der Yayınları, s. 31.

7 Touchard, s. 62; Doehring, s. 192.

8 Şenel, Alaeddin (1995) Siyasal Düşünceler Tarihi, 4. Kısaltılmış Bası, Bilim ve Sanat Yayınlar1, s. 210-211.

9 Vile, M.J.C. (1998) Constitutionalism and the Separation of Powers, 2. Bası, Indianapolis, Liberty Fund, s. 26. 
derinden etkilediği kabul edilen Bolinbroke, İngiltere'de parlamentonun, kraliyet bakanlarının her dediğini onaylayan bir araç haline gelmesine karşı çıkmış ve yasamanın yürütmeden bağımsız olmasını savunmuştur. ${ }^{10}$ Bu bağlamda geliştirilen kuvvetler ayrılığ 1 kavramı on sekizinci ve on dokuzuncu yüzyıllarda bilimsel çerçeveye oturtulmuştur. Öte yandan on üçüncü yüzyılda Magna Carta ile İngiliz Kralının yetkilerinin sınırlandırılmasına yönelik gelişmeler de güçler ayrımı anlayışıyla bağdaştırılabilmektedir. ${ }^{11}$

Anayasacılığın özünü oluşturan siyasi iktidarın sınırlanması düşüncesi ile kuvvetler ayrılığı teoremi Orta Çağ da John Locke tarafından ortaya atılmıştır. On yedinci yüzyılda mutlakiyetçi devlet anlayışına ağır bir darbe indiren Locke, liberal devlet sisteminin öncüsü olarak kabul edilmektedir. 1690 yılında "Hükümet Üzerine İnceleme" ${ }^{12}$ adlı çalışmasıyla kuvvetler ayrılığı teorisinin temellerini oluşturmuştur. Kuvvetler ayrılığı yaklaşımı daha sonra Fransız filozof Montesquieu'nun 1748 yılındaki "Yasaların Ruhu Üzerine"13 adlı çalışmasıyla geliştirilmiş ve modern dönemdeki formunu kazanmıştır. Çalışmamızda kronolojik gelişimine uygun olarak önce Locke'un, ardından Montesquieu'nun erkler ayrımına, son olarak Rousseau'nun kuvvetler ayrılığ karşıtı siyaset teorisine yer verilecektir. Düşünürlerin kuvvetler ayrıllğ̆ ilkesinin gelişimine katkıları ele alınacaktır.

\section{LOCKE’TA KUVVETLER AYRILIĞI TEORİSI}

Diğer doğal hukuk savunucuları gibi John Locke da liberal özgürlük temeline dayalı siyaset anlayışını ifade etmek üzere insan unsuru ve doğal yaşamın özelliklerinden yola çıkmaktadır. Locke’a göre insan sosyal bir varlık olarak yaratılmıştır. Bu nedenle birey, doğası gereği toplum içinde yaşamak zorundadır. Toplum içinde yaşayan sosyal bir varlık olarak insan aynı zaman-

10 Schulze, Hagen (2005) Avrupa'da Ulus ve Devlet, Binder, Timuçin (Çev.), İstanbul, Literatür Yayınları, s. 74.

11 Doehring, s. 193.

12 Locke, John (1940) Of Civil Government, New York, J. M. Dentand Sons Ltd. London / E. P. Duttonand Co. Inc. (Eserin 1940 yılına ait bu basımında "Hükümet Üzerine İnceleme" ile "Hükümet Üzerine İkinci İnceleme" tek cilt olarak birlikte basılmıştır).

13 Montesquieu (2017) Yasaların Ruhu Üzerine, Günen, Berna (Çev.), 2. Bası, İstanbul, İş Bankası Kültür Yayınları. 
da doğal olarak eşit ve özgürdür. İnsanlar başkalarından izin almaya gerek görmeden kendi istek ve iradeleriyle bu doğal yaşam durumundan çıkarak siyasal bir iktidara boyun eğmeyi kabul etmişlerdir. İnsan yaşamlarının ve vücut bütünlüklerinin korunması, güvenli bir ortamda mallarını rahatça kullanabilmek için, kötülüklere karşı daha iyi korunabilmek için siyasal toplumu kurmuşlar ve hükümeti oluşturmuşlardır. Siyasal toplum, kendini oluşturan her bireyin rızasıyla kurulduğu için, toplumu hareket ettirecek olan güç olan iktidar da çoğunluğun istek ve iradesine dayanmaktadır. ${ }^{14}$

\section{A. YASAMA-YÜRÜTME-FEDERATIFF ERKLER AYRIMI}

Locke'un düşüncesinde toplumu oluşturan bireyler, aralarında yaptıkları sözleşmeyle doğa durumuna son verip, yaşanan anlaşmazlıkları çözümleyecek, suçluları cezalandıracak olan bir otoritenin tesis edileceği siyasal toplum durumuna geçerler. ${ }^{15}$ Böylece bütün insanların müşterek ihtiyacı olan güvenlik ihtiyacı iktidar tarafından karşılanmış olacaktır. Bu anlamda siyasal toplum dışında olan kimseler tarafından ya da toplum içinde yasalara uymayanlar tarafından toplum üyelerine verilebilecek zararları önleme gücüne sahip bir yapılanma meydana getirilmiştir. Bu yapılanmada yasa koyma ve yasaları uygulama işlevlerini yerine getirmek üzere yasama ve yürütme organları mevcuttur. Bu düşünce örgüsüyle Locke söz konusu kuvvetler ayrımını doğa durumu ve doğal hukuk kavramları üzerine inşa etmiştir. ${ }^{16}$ Ancak modern anlamdaki kuvvetler ayrılı̆̆ında yasama ve yürütmenin yanındaki üçüncü erk yarg1 iken, Locke'un düşüncesinde yasama ve yürütmenin yanındaki üçüncü erk federatif erktir.

Locke'un erkler ayrımı düşüncesinde, yürütme ve federatif erklere nazaran yasama erkinin siyasal toplumda ilk biçimlenen erk olduğu ve üstün mahiyet arz ettiği kabul edilmektedir. Yasama gücü, toplumu ve üyelerini korumak için oluşturulmuş devlet güçlerinin nasıl kullanılacağını belirleyen

14 Locke, John (1952) The Second Treatise of Government, New York, The Liberal Arts Press, s. 55.

15 Locke (1952), s. 6.

16 Jenkins, David (2011) 'The Lockean Constitution: Separation of Powers and the Limits of Prerogative’, Mc Gill Law Journal, C: 56, S: 3, ss. 543-589, s.547. 
iktidardır. Siyasal toplum düzeninin kurulmasıyla izlenen amaçların gerçekleşebilmesi için öncelikle yasama gücünü tesis etmek gerekir. Yasama kutsal, üstün, egemen bir güçtür ve siyasal toplum kurulurken bu gücü kime vermişse gücü kullanma yetkisi ona ait olur. Bu üstünlük nedeniyle diğer erkler yasamaya tabidir. Özellikle yürütmenin olağanüstü durumlarda bile her zaman yasamaya hesap vermek zorunda olduğu kabul edilmiştir. ${ }^{17}$ Öte yandan can güvenliği ve mülkiyet haklarının korunmasını sağlayan bir siyasal toplum ya da bu toplumun yasama iktidarı, kamu iyiliğinin gerektirdiği sınırların ötesine geçemez. ${ }^{18}$ Egemen gücün ya da yasama iktidarının tek amacı toplumun iyiliği, huzuru ve güvenliğini sağlamaktır. Bu amacını gerçekleştirirken de kendisine devredilen yetkileri kullanmada ortak iyiliğin sınırlarının ötesine geçemeyecektir.

Yürütme erkine ilişkin tanımlayıcı tespitlerinde Locke, yürütmeyi toplum yasalarının sürekli bir biçimde uygulanabilmesi için yasaların icrasını gözetecek bir güç olarak değerlendirmektedir. ${ }^{19}$ Yürütme erki, toplumun yasalarının toplum içinde yürütülmesini, kamu güvenliği ve çıarının gözetilmesini üstlenmiştir. Bu çerçevede yürütme önceden çıkarılmış pozitif yasalar tarafından belirlenmiş sınırlar içinde görev yapar. Yürütme erki, federatif erk ile birlikte yasama erkine ihtiyaç duyar; bu bakımdan iki ayrı erk olarak var oldukları halde çoğunlukla birleşik şekilde işlev gördükleri söylenebilir. ${ }^{20}$

Yasama ve yürütme ayrımı odaklı geliştirdiği kuvvetler ayrıllğ̆ teorisinde Locke üçüncü bir güç olarak federatif erki öngörmüştür. Federatif iktidar, savaş ve barış yapma, birlikler ve ittifaklar oluşturma, devletsiz kişi ve topluluklarla işlem yapma yetkisine sahiptir. ${ }^{21}$ Federatif erk, dıştan gelebilecek yarar ya da zararlara ilişkin kamu güvenliği ve toplum menfaatinin gerektirdiklerini yapma işlevine sahiptir.

Yargılama yetkisini yasama, yürütme ve federatif erkler bünyesinde değerlendiren Locke, "Hükümet Üzerine İnceleme"de toplum mensuplarının

\footnotetext{
7 Jenkins, s. 546-547.

18 Locke (1952), s. 110-111.

19 Locke (1952), s. 82-83.

20 Locke (1952), s. 83-84.

21 Locke (1952), s. 83.
} 
sözleşmesi üzerine inşa olunmuş yargılama gücüne ilişkin düşüncelerini şekillendirmektedir. Toplumsal sözleşme dayanak yapıldığında toplum üyelerinin doğal hakları teminat altına alınmakta, buna karşılık sivil iktidar ceza vermek ve adalet dağıtmak üzere yargı yetkisine sahip kılınmaktadır. Ayrı bir erk olarak değerlendirmediği bu yargılama yetkisini Locke üçe bölünmüş bir iktidar alanı olarak düşünmektedir. Buna göre bağımsız erklerden birincisi, toplum olarak birlikte yaşamanın gerektirdiği kuralların hangi hallerde ihlal edilmiş sayılacağını ve ihlal durumunda uygulanacak cezaları belirleyebilen yasama gücü; ikincisi, yasama organı tarafından çıkarılan spesifik yasaları yürütmek üzere dizayn edilmiş olan yürütme gücü; üçüncüsü, devletin diğer devletlerle ilişkilerini yürütmekle yükümlenmiş olan federatif güçtür. Bu üçlü ayrıma dayanan Locke'un düşüncesinde yargıdan ayrı bir siyasal erk olarak söz edilmemektedir. ${ }^{22}$

Görüldügü üzere Locke, yasama ve yürütme erklerinin ayrilığına vurgu yaparken yargı erkini ağırlıklı olarak yürütmenin bir tür uzantısı olarak değerlendirmiş, ayrı bir erk olarak tasarlamamıştır. Bu bakımdan Montesquieu'nun geliştirdiği yaklaşımın aksine yargı erki Locke'ta muğlak bir mahiyet arz etmektedir. Buna karşın yasaları koyanlar ile uygulayanların ayrı kişiler olması gerektiği düşüncesiyle yasama-yürütme ayrımı öncelik kazanmıştır. Yasama ile yürütme ayrımına odaklanmış olan Locke'un siyaset felsefesinde biçimlenen kuvvetler ayrımı, esasında yönetime karşı bireysel hak ve özgürlüklerin daha iyi korunmasını sağlayan bir düzenektir. ${ }^{23}$ Locke, kuvvetlerin tek elde toplanmasının sakıncalarına dikkat çekmiştir ancak; üçlü kuvvetler ayrılığı fikrini günümüzdeki anlamıyla fren ve denge sistemine dayalı olarak tasarlamamıştır. ${ }^{24}$

Locke'un kuvvetler ayrılığı teorisinde bir başka özellik yürütme gücünün ve federatif yetkinin yasama gücüne tabi olduğunu kabul etmesidir. ${ }^{25}$ "Hükümet Üzerine İkinci İnceleme”nin "Yasama İktidarının Kapsamı Üzeri-

22 Uygun, Oktay (2017) Devlet Teorisi, 3. Bası, İstanbul, On İki Levha Yayınları, s. 224.

23 Şenel, Alaeddin (1995) Siyasal Düşünceler Tarihi, 4. Kısaltılmış Bası, Ankara, Bilim ve Sanat Yayınları, s. 343.

24 Uygun, s. 224.

25 Göze, Ayferi (2016) Siyasal Düşünceler ve Yönetimler, 16. Bası, İstanbul, Beta Yayınları, s. 181. 
ne" başlıklı bölümünde devletler oluştuğunda ilk ihtiyaç duyulan temel pozitif yasanın, yasama organının oluşturulmasına ilişkin yasa olduğunu kabul eder. $\mathrm{Bu}$ nedenle yasama iktidarı üstündür ve bir kez yasama erkini kullanma yetkisine sahip kılınan kişiler kolayca değiştirilemez. Diğer erkleri kullanan organlar da yasama organına itaat etmekle yükümlüdür. ${ }^{26} \quad$ Locke'un yasama erkini, yürütme ve yarg1 erkinin üzerinde değerlendirmesi ${ }^{27}$ ve kuvvetler ayr1lığını üçlü ayrım çerçevesinde olmazsa olmaz bir prensip olarak tanımlamamış olması eleştiri konusu edilmiştir.

Locke'un yargı erkini yürütme erkinin bir unsuru olarak tanımlaması ve yasama-yürütme-federatif erkler şeklindeki üçlü ayrımının kuvvetler ayrılığ 1 ilkesini tam olarak öncelememesi, onun kuvvetler ayrılığı anlayışına katk1larını farklı bir boyutta ele alınmasını getirmiştir. Oysa modern anayasalarda benimsenen erkler ayrımı yasama-yürütme-yargı üçlüsü olarak biçimlenmiştir. Buna göre modern anayasacılık çalışmalarında Locke'un düşüncesini, Montesquieu'nun düşüncesinden farklı bir işlevle konumlandırma anlayışının geliştiğini ifade etmek yanlış olmayacaktır. ${ }^{28}$

\section{B. ÜSTÜN YASAMA ERKİNINN SINIRLILIĞI İLKESI}

Locke’a göre siyasal (uygar) toplumda birey özgürlüklerinin kısıtlanması hususunda yönetimden kaynaklanan birtakım riskler mevcuttur. Bu risklerden birincisi, yasa yapma erkini elinde tutan gücün yürütme erkini de ele geçirebilecek olması ya da yürütme erkinin yasa yapma yetkisini ele geçirmesi durumudur. Yönetimden kaynaklanan ve birey özgürlüklerine yönelebilecek ikinci tehlike, yasaları yapan yasama mensuplarının ya da yasaları uygulayan yürütme mensuplarının kendilerini, yasalara uyma yükümlülüğü altında görmemeleridir. Üçüncüsü risk konusu ise iktidarı kullananların, gerek yasa yapımı aşamasında gerekse yasaların yürütülmesi aşamasında yasaları kendi çıkarlarına göre şekillendirmesi ve kendi yararları doğrultusunda kullanmalarıdır. Yönetenlerin yönetilenlerin doğal haklarına ve bireysel özgürlüklerine

26 Locke (1952), s. 75-76.

27 Locke (1952), s. 50.

28 Ratnapala, Suri (1993) 'John Locke's Doctrine of the Separation of Powers: a Re-Evaluation', The American Journal of Jurisprudence, C: 38, S: 1, ss. 189-220, s. 189. 
yöneltebilecekleri bu üç tehlikeye karşı korunabilmesi amacıyla yönetim erkinin ikiye ayrılması zorunluluktur. ${ }^{29} \mathrm{Bu}$ gerekçelere dayandırılarak Locke'un kuvvetler ayrılığı teoremi, yasaları yapanlarla uygulayanların farklı kişiler olması gerektiği düşüncesi ekseninde gelişmiştir. ${ }^{30}$

Yasama erkinin diğer erklere kaynaklık ettiğinin ve onlardan üstün olduğuna ilişkin görüşe yukarıda yer verilmişti. Bu bağlamda Locke, Montesquieu'dan farklı olarak erklerin sınırlandırılmasından ziyade üstün olan yasama iktidarının sınırlandırılması gereği üzerinde durmuştur. Yasama iktidarının sınırlılı̆̆ı ilkesini "Yasama İktidarının Kapsamı Üzerine” başlıklı on birinci bölümde üç dayanak üzerinde kurmuştur.

İlk dayanak olarak, egemen gücün ya da yasama iktidarının tek amac1nın toplumun iyiliği, huzuru ve güvenliğini sağlamak olduğu prensibi esas alınmıştır. Bu amacını gerçekleştirirken de yasama erkinin kendisine devredilen yetkileri kullanmada ortak iyiliğin sınırlarının ötesine geçemeyeceği öngörülmüş̧ür. Locke, toplumun yasama iktidarının diğer erklerden üstün olduğunu vurgulamasına karşın, kamu iyiliğinin gerektirdiği sınırların ötesine geçemeyeceğini kabul etmektedir. ${ }^{31}$ Egemen gücün ya da yasama iktidarının tek amacı toplumun iyiliği, huzuru ve güvenliğini sağlamaktır. Bu amacını gerçekleştirirken de kendisine devredilen yetkileri kullanmada ortak iyiliğin sınırlarının ötesine geçemeyecektir. Bu tezleriyle yasama gücünün sınırlılığını doğal haklara dayanarak temellendiren Locke, bir yandan yasamanın üstünlügüne, parlamentonun kutsallığına vurgu yaparken, öte yandan kesin şekilde yasama yetkisinin keyfi kullanılamayacağını savunmaktadır. ${ }^{32}$ Yasamacı olarak tayin edilen kişi ya da kurul kim olursa olsun, toplumun her bir üyesinin doğa durumunda sahip olduğu yetkilerin toplamıdır. Dolayısıyla toplum bireylerinden devralınan bu yetki devrolunandan fazlası olamaz. Kimse kendisinin sahip olduğu iktidardan daha fazlasını devredemez. Sonuç olarak yasama iktidarının yetki sınırları toplumun kamusal yararının sınırlarını aşamaz. ${ }^{33}$

\footnotetext{
Locke (1952), s. 81-82.

Şenel, s. 344.

Locke (1952), s. 110-111.

Akın, İlhan F. (1993) Kamu Hukuku, 7. Bası, İstanbul, Beta Yayınevi, s. 137.

Locke (1952), s. 76-77.
} 
Üstün yasama iktidarının sınırlılı̆ğ ilkesinin ikinci dayanağı, yasama tasarruflarının genel yasalar biçiminde gerçekleşmesi kuralıdır. Yasalar gelişigüzel alınan keyfi kararlar değildir. Kişilerin can ve mal varlıklarını korumayan, keyfi şekilde verilmiş kararlar, siyasal toplumun varlık ve kuruluş amacına ters düşer. Toplumu oluşturan bireyler, doğal yaşama döneminde bulundukları durumdan daha geri bir duruma düşmek için değil, bu dönemde sahip oldukları değerleri güvence altına almak için siyasal toplumu oluşturmuşlardır. Dolayısıla toplumun sahip olduklarını korumayan yasalar yasama iktidarı tarafindan kabul edilemez. ${ }^{34}$

Üçüncü ve son dayanak olarak hiçbir üstün gücün, herhangi bir bireyin mülkiyetinde bulunan eşyaya bireyin rızası olmaksızın dokunamayacağı kabul edilmektedir. Bireylerin sahip oldukları maddi değerler kutsal ve dokunulmaz niteliktedir. Kuşkusuz yönetimlerin giderlerini karşılamak üzere vergi alması meşrudur, çünkü mülkiyet üzerinde vergilendirme formunda gerçekleşen bu müdahale, bireylerin ya da toplum çoğunluğundan oluşan iradeye dayalıdır. Toplumsal iradeye ya da bireyin rızasına dayanmayan müdahaleler mülkiyet hakkının hilafına, dolayısıyla toplumun kuruluş amacına aykırı şekilde gerçekleşmiş olacaktır. ${ }^{35}$

Locke'un yasama yetkisinin sınırlarına ilişkin bir diğer vurgusu yasama yetkisinin devredilmezliğine ilişkindir. Üstün yasama gücü, yasamadan kaynaklanan yetkilerin el değiştirebilmesini kapsamaz. Yasama gücünü kullananlar bu gücü başkasına devredemez, çünkü sadece halk yasama iktidarını kullanacak kişi ya da kurulu belirleyebilme hakkına sahiptir. ${ }^{36}$

"Yönetim Üzerine İkinci İnceleme”nin "Gasp Üzerine” (Of Usurpation) başlıklı on yedinci bölümünde Locke, on birinci bölümde belirlediği ilkelerin hilafına iktidarın yetkisini aşmasını, iktidar gaspını bir tür iç fetih olarak tanımlamıştır. Gaspçı bir iktidarın, devletin meşru prenslerine ya da yöneticilerine hak olarak verilmiş olanın ötesine geçmesiyle oluşacak durum, gaspa ekli tiranlıktır. ${ }^{37}$ Topluluk yasalarının öngördüğü usullerin dışındaki yollardan

\footnotetext{
34 Locke (1952), s. 77-78.

35 Locke (1952), s. 79-80.

36 Locke (1952), s. 81.

37 Locke (1952), s. 110-111.
} 
iktidarın parçalarının kullanımına katılan bir yönetici söz konusu olursa, bu kişi kim olursa olsun devlet biçiminin sürmesine karşın itaat edilme hakkı yoktur. Çünkü bu kişilerin yasalara uygun şekilde iktidara gelmediklerinden veya iktidarı yasal sınırlar içinde kullanmadıklarından dolayı toplumu oluşturan bireylerin onayını almadığı kabul edilir. Bu anlamdaki gaspçı yönetici ya da ondan türeyen kişi; gerek halkın onay verme hürriyetine sahip olmasına kadar, gerekse iktidarın söz konusu kişide kalmasına izin vermeyi veya kişiyi onaylamayı fiili olarak ortaya koymasına kadar, gasp edilmiş bulunan iktidara dair hiçbir yetkiye sahip değildir. ${ }^{38}$

“Tiranlık Üzerine” (Of Tyranny) başlıklı on sekizinci bölümde Locke, iktidar yetkisinin aşılması durumunu değerlendirmeyi sürdürmekte ve tiranlığın nasıl anlaşılması gerektiği üzerinde durmaktadır. Buna göre gasp, başkasının sahip olduğu iktidarın kullanılması iken; tiranlık da hiç kimsenin üzerinde hak sahibi olmadığı hakkın ötesindeki iktidar kullanımıdır. ${ }^{39}$ Eğer hükümdar kim olursa olsun- kendisine yasayla verilmiş olan iktidarı aşar ve emri altındaki gücü, yasaların izin vermemesine karşın uyruklarını kuşatmak için kullanırsa yönetici sıfatını kaybeder. Bu durumda yetki sahibi olmadan yapacağı her şeyden sanki başkasının hakkını gasp eden herhangi biriymiş gibi tecavüzde bulunmuş addedileceğinden hükümdara karşı gelinebilecektir. ${ }^{40}$ Locke, hükümdarın kendi yetki sınırlarını aşarak yağmalama ve baskı kurma yoluna gitmesi durumunun mazeret kabul edemeyeceğini vurgularken, en üstün yetkilere sahip olan hükümdarın yetkisini aşmasını, daha az yetkiye sahip alt düzey bir yöneticinin yetkisini aşmasından daha ağır bir durum olduğuna dikkat çekmektedir. ${ }^{41} \mathrm{Bu}$ argümanların devamında ise Locke, direnme hakkına ilişkin tezlerini öne sürmekte; yöneticinin direnme hakkını kullanmak isteyen topluma sayg1 göstermek zorunda bulunduğuna vurgu yapmaktadır. ${ }^{42}$

\footnotetext{
38 Locke (1952), s. 111.

39 Locke (1952), s. 112.

40 Locke (1952), s. 114.

$41 \quad$ Locke (1952), s. 115.

42 Göze, s. 184.
} 


\section{MONTESQUIEU'NUN KUVVETLER AYRILIĞI DOKTRINI}

Güçlerin ayrılması yaklaşımı ile Locke, liberal devlet öğretisinin en önemli unsurunu ortaya koymuştur. Onun bu görüşünü daha ileriye götüren kişi ise Baron de Montesquieu'dur. Siyaset biliminin kurucusu olarak kabul edilen Montesquieu'yu, ilk pozitivistler arasında değerlendiren görüşler mevcuttur. ${ }^{43}$ Montesquieu'nun iktidarın kontrolü ve denge sağlamaya yönelik kuvvetler bölüşümü olarak da adlandırılan teorisi 1748 yılında yayımlanan “De L'esprit Des Lois” (Yasaların Ruhu Üzerine) adlı eseriyle tanınmıştır. İktidar odaklarını Montesquieu birbirini frenleyip dengeledikleri bir sistem içinde ele almıştır. Üçlü kuvvetler ayrılığı anlayışını hem betimleyici hem kuramsal bir yaklaşımla oluşturmuştur. ${ }^{44}$

\section{A. YASAMA-YÜRÜTME-YARGI AYRIMI}

"Yasaların Ruhu Üzerine" adlı eserinin başlangıcında Montesquieu, yasa koyucunun niyet ve hedeflerinin ötesinde yasaların yapılmasına hâkim olan ilkeleri ortaya koymuştur. Montesquieu, toplumları yöneten yasaların da başka yasalara bağlı olduğunu göstermek istemiştir. ${ }^{45}$ Yasaların bulunduğu bir toplumda -devlet düzeninde- özgürlügün anlamı da bireyin yasalar çerçevesinde isteyebileceklerini istemesi, yasalara göre isteyemeyeceklerini de istememesidir. Başka bir deyişle özgürlük, yasaların izin verdiği her şeyi yapabilmek ve izin vermediklerini yapmamaktır. ${ }^{46}$ Buna göre özgürlükten söz edebilmek için, iktidarın kötüye kullanılmadığı ılımlı yönetimler gereklidir. İktidar yetkilerinin kötüye kullanılmasını önlemenin yolu da iktidarı iktidarla durdurmaktır, frenlemektir. Herhangi bir siyasal düzende özgürlüğün var olup olmadığını ölçmek için, iktidarın iktidarla sınırlandırılmış olup olmadığina bakmak gerekmektedir. ${ }^{47}$

43 Göze, s. 194.

44 Ağaoğulları, Mehmet Ali / Zabçı, Filiz Çulha / Ergün, Reyda (2009) Kral Devletten Ulus Devlete, 2. Bası, Ankara, İmge Kitabevi, s. 422.

45 Montesquieu (2017) Yasaların Ruhu Üzerine, Günen, Berna (Çev.), 2. Bası, İstanbul, İş Bankası Kültür Yayınları.

46 Montesquieu, s. 196-197.

47 Montesquieu, s. 197. 
Montesquieu kuvvetler ayrılığını günümüzde kullanılan biçimiyle, yasama yürütme ve yargı erkleri ayrımına dayalı olarak ilk kez formüle etmiştir. Onun geliştirdiği kavramsallaştırmaya göre her devlette yasama, yürütme ve yargı olmak üzere üç tür erk mevcuttur. ${ }^{48}$ Montesquieu'nun kuvvetler ayrıllğ 1 doktrini, İngiliz Anayasasında birbirinden ayrılmış yasama yürütme ve yargı erklerinin despotluğa kaymayı önleyecek şekilde birbirini denetlemesine dayalı olduğu varsayımını temel almıştır. İngiliz anayasal sisteminde, kralın yürütme, parlamentonun yasama, mahkemelerin de yargı erkini elinde bulundurduğunu değerlendirmiş ve kendi içinde eksikleri bulunan bu uygulamanın sisteminden esinlenmiştir. Bu doğrultuda Fransa'da da temel hak ve özgürlüklerin teminat altına alınabilmesi için yasama yürütme ve yargı erklerinin ayrı organlara verilmesi gerektiğini savunmuştur. ${ }^{49}$

Aslında dönemin İngiliz siyasal sistemindeki gelişmeler bir yanıyla katı kuvvetler ayrılığına dayalı başkanlık sistemine esin kaynağı olurken, öte yandan yumuşak kuvvetler ayrılığı sistemine dayalı parlamenter sisteme dönüşme sürecindeydi. İngiliz siyasetindeki yapısal değişiklikler 1787 Anayasası başkanlık sistemi modeline yol göstericilik yapmıştır. Bununla birlikte Lordlar Kamarasının yetkilerinin kısıtlanmasıyla şekillenen yasamanın kısıtlanması süreci de İngiliz siyasal sistemini parlamenter sisteme yönlendirmiştir. ${ }^{50}$

Dönemin İngiliz kamu hukukunda yaşanan gelişmelerin etkisi altında kalan Montesquieu, Locke'un yasama-yürütme-federatif erkler ayrımının yerine yasama-yürütme-yargı ayrımını getirmiştir. Yasa koyma, değiştirme ve kaldırma yetkisine sahip olan yasama erki genel iradenin temsilcisidir. Yasaların iyi uygulanıp uygulanmadığını denetlemekle yükümlüdür. Montesqieu, halkın temsilcilerinden oluşan meclisin yanında soyluların temsilcilerinden oluşan ikinci bir meclis öngörmüştür. Bu iki meclis ayrı ayrı toplanacak ve farklı bakış açılarına sahip olacaktır. ${ }^{51}$ Bu meclisler İngiliz siyasal sistemindeki adıyla Lordlar Kamarası ile Avam Kamarasıdır.

\footnotetext{
48 Montesquieu, s. 198.

49 Şenel, s. 353-354.

50 Göze, s. 208, 490, 509.

51 Montesquieu, s. 203.
} 
İkinci mecliste üyelik babadan oğula geçeceği için kendi menfaatleri doğrultusunda tercihte bulunabileceği düşüncesiyle bu meclise vergi koyma gibi konularda karar verme yetkisi tanınmamıştır. ${ }^{52}$ Montesqieu, iki meclisli yapının gerekliliğini toplumda mevcut iki sınıfın çıkarlarının dengelenmesi ihtiyacına ve karşılıklı kontrol sağlama ihtiyacına dayanarak açıklamıştır.

Montesquieu'nun siyaset teorisinde yürütme erki genel iradenin yürütülmesi olup, bu işlevi yerine getirmek üzere tayin edilen organın savaşa ve barışa karar verme yetkisini kullanarak gerekli güvenlik tedbirlerini alması öngörülmüştür. Yürütme organı yabancı devletlere temsilci gönderir ve yabancı temsilcileri kabul eder. ${ }^{53}$ Montesquieu, yürütme erkinin yasama organı içinden seçilecek bir kişi ya da kurula verilmesini, kuvvetlerin birbirinden ayrılması yaklaşımıyla bağdaştırmadığı gerekçesiyle yürütme erkinin monarka ait olduğunu kabul etmiştir.

Montesquieu'nun üçlü kuvvetler ayrımında yer verdiği yargı erkini, diğer erklerden daha sonra teorisine dâhil ettiği öne sürülmektedir. ${ }^{54}$ Üçüncü erk olan yargı, uyuşmazlıkları çözümleyerek yaptırım uygulanmasına karar veren bir güç olarak tasarlanmıştır. ${ }^{55}$ Buna göre yargılama görevinin, halk tarafından seçilen mahkemelerce yerine getirilmesi gerekmektedir. Yargı yetkisini kullanan kişilerin, yasalarla ilgili olarak yorum yapmadan, inisiyatif kullanmadan, tıpatıp uygulama görevini icra etmeleri öngörülmüştür. ${ }^{56}$

Yarg1 erki, bir tür jüri sistemi ve habeas corpus aracılığıyla yurttaşların siyasal özgürlügüne güvence oluşturacaktır. Yargıçların halk tarafından seçilmesi ve belirli bir süreyle sınırlı olarak görev yapmaları öngörülmüştür. Yargı erkini kullanan mahkemelerin, sürekli olarak bu görevde bulunmamaları gereklidir. Eğer süreklilik ve bir düzen içinde bu görev ifa edilirse bir süre sonra kuvvetlerin birleşmesi sonucu ortaya çıkacaktır. Bu özellikleri yargı organını,

52 Montesquieu, s. 204.

53 Montesquieu, s. 198.

54 Flaherty, Martin S. (2006) 'The Most Dangerous Branch Abroad', Harward Journal of Law and Public Policy, C: 30, S: 1, ss. 153-171, s. 161.

55 Săraru, Cătălin-Silviu (2015) 'The State and the Separation of Powers', Juridical Tribune, C: 5, S: 2, ss. 274-280, s. 278.

56 Montesquieu, s. 200. 
yasama ve yürütme organından farklılaştırmaktadır. ${ }^{57}$ Montesquieu yargıyı, yasaların lafzından fazlasıyla uğraşmayan, pek bir yaratıcı işlevli olmayan erk olarak nitelemiştir. Böylece yargı erki, yasama ve yürütmeden farklı olarak siyasal bakımdan etkin ve hukuksal bakımdan biçimlendirici olmayan bir devlet gücü olarak konumlandırılmıştır. Yargıya ilişkin bu konumlandırma şeklinin, ne Anglo-Sakson hukuk modeliyle ne de Kita Avrupası hukukunda gelişen içtihat hukuku anlayışıyla bağdaşmadığını belirtmek gerekir. ${ }^{58}$

Montesquieu, siyasal özgürlüğün sağlanmasını ve sürdürülmesini yasama, yürütme ve yargı erkinin farklı ellere verilmesine bağlamıştır. Eğer bir devlette yasama, yürütme ve yargı yetkileri aynı kişi ya da organda toplanırsa özgürlük ortadan kalkar. Sadece yasama erki ile yürütme erki aynı kişide ya da kurulda birleştiğinde yine özgürlükten söz edilemeyecektir. Çünkü bu durumda aynı monarkın ya da kurulun yasaları despotça uygulamak için despotik yasalar çıkarması olanaklı hale gelmektedir. ${ }^{59}$ Yargı erkinin yasama erkiyle ya da yürütme erkiyle birleştiği durumda da yine özgürlük söz konusu olamaz. Çünkü böyle bir durumda birey özgürlüklerini ve yaşamlarını tehlikeye sokan bir güç meydana gelmiş olur. Bu üç erk, ister bir kişi, ister yüksek memurlar, ister aristokratlar ve isterse halk olsun, aynı kesimin elinde toplandığı takdirde devletteki her şey yıkılır. ${ }^{60}$

\section{B. ERKLER ARASINDAKİ İLIŞKİLER}

Modern kuvvetler ayrıllı̆ı anlayışının temel unsurlarından biri, üçlü erkler ayrımı iken bir diğeri de bu erkler arası ilişkilerdeki dengedir. Yasama, yürütme ve yargı erkleri net hatlarla birbirinden ayrılmış olsa da tümüyle kopuk olmaları kabul edilmez. Montesquieu'nun kuvvetler ayrılı̆̆ 1 teorisinde de kuvvetler arasındaki ilişkilerde belirli bir denge sistemi bulunduğu kabul edilir.

Yasama ile yürütme erkleri arasındaki ilişkiye dair söylenebilecek ilk özellik, yasama organının yürütmenin çağrısı üzerine toplanabilmesidir. Ya-

\footnotetext{
Ağaoğulları / Zabçı / Ergün, s. 424.

Doehring, s. 196.

Montesquieu, s. 199.

60 Montesquieu, s. 199-200.
} 
sama organının kendiliğinden toplanma ya da toplantılarına son verme hakkı yoktur. Çünkü bir meclis ancak bütün şeklinde toplandığı andan itibaren iradeye sahip kabul edilir. Dolayısıyla toplanma ya da dağılma kararlarında oybirliği sağlanmadığı takdirde bir meclis iradesinden de söz edilemez. Toplanma ya da tatil edilme konusunda yasamanın kendi başına karar verebilme yeteneği olursa yasama erki mutlaklaşır. ${ }^{61}$

Yasamayı toplantıya çağırma yetkisine sahip kılınmış olan yürütme organının da bu yetkiyi kullanırken belirli sınırlar dâhilinde hareket etmesi gerekmektedir. Yürütmenin yasamayı uzun süre toplanmaya çağırmaması, aralarındaki dengeyi bozacak ve yürütmenin mutlaklığı nedeniyle özgürlük ortamını kaldıracaktır. Bu nedenle yürütmenin yasamayı her yıl toplantıya çağırması zorunluluktur. Yürütmenin hazırladığı bütçenin de her yıl yasama tarafından onaylanması ve daimi ordunun beslenmesine de meclisin karar vermesi gerekmektedir. Bununla birlikte bu konuda yapılacak yasama toplantılarının ne zaman gerçekleştirileceğini ve ne kadar süreceğini belirleme yetkisi yürütmede kalacaktır. ${ }^{62}$

Yürütmeyle ilgili bir başka özellik, monarkın yasama işlemlerini durdurma hakkına -veto yetkisine- sahip olmasıdır. Meclisin despotik bir erk haline gelmemesi için yasama organının yapmaya yetkili olduğu işlerin yürütme organı tarafından engellenebilir olması gerekli görülmüştür. Bu engellemenin anlamı kralın veto hakkını kullanarak yasama alanına karışabilmesidir. ${ }^{63}$ Yasama organının zorbalığa meyletmemesi için monarkın böyle bir yetkiye sahip olması kabul edilmiştir. Öte yandan bu durum yasamanın karar alma sürecine yürütmenin müdahale edebileceği anlamına gelmez. Monark, yasamanın karar alma aşamasına karışamayacağı halde, alınmış olan bir kararın uygulanmasına karşı tavır alabilir. Başka bir deyişle yasa çıkarılmasına müdahale edemez, veto yoluyla yasaların yürürlüğe girmesini engelleyebilir. ${ }^{64}$ Yine de monarkın bu yetkiye sahip kılınmasını eleștiren bir görüş gelişmiştir. Montesquieu'nun kuvvetler ayrılığı düşüncesinin gerçek bir yetki paylaşımını

\footnotetext{
61 A ğaoğulları / Zabçı / Ergün, s. 427.

62 Montesquieu, s. 204-205.

63 Montesquieu, s. 205-206.

64 Göze, s. 210.
} 
öngörmediğini savunan bu görüşe göre, monarkın veto yetkisi kullanarak yasamaya müdahale edebilmesi erklerin tam olarak birbirinden ayrılmadığ1nin emaresidir. ${ }^{65}$

Montesquieu'nun yürütme erki için tasarladığı veto yetkisi hakkında belirtilen hususlar çerçevesinde, yasama erki tarafından yürütmeye yönelik olarak herhangi bir müdahalede bulunma yetkisi söz konusu olmadığını vurgulamak gerekir. Yasamanın yürütmeye karşı veto aracılığıyla denge mekanizması oluşturması, yürütmenin yasaların çıkarılmasını değil, yasaların uygulamasını denetlemek suretiyle mümkün kılınmıştır. ${ }^{66}$ Çünkü doğası gereği zaten sınırlı olan, yasamanın belirlediği yasal sınırlar içinde var olabilen yürütmeyi daha da sınırlandırmak, erkler arası dengenin özgürlükler aleyhinde bozulmasina sebep olabilir.

Devletin özgür olmayan bir cumhuriyete ya da halk despotluğuna dönüşmemesi adına kabul edilen bir başka ilke, hükümetin başı olan monarkın dokunulmazlık zırhında kabul edilmesidir. Özgür devletin temsilcisi olan kralın kişiliği kutsal sayılmalıdır. Yürütme organı olan monarkın, kutsal ve dokunulmaz olması nedeniyle yürütmeyi suçlamak ya da yargılamak mümkün değildir. Ancak yürütmenin yasaları kötü uygulaması durumunda, bunun nedeni kötü danışmanların seçilmesi ise, bu kötü danışmanlar suçlanabilir ve cezalandırılabilir. ${ }^{67}$

Montesquieu'nun yaklaşımında yasama ve yürütme erkleri arasında kurulmak istenen bir fren ve denge mekanizması mevcuttur. Yasama erki için olduğu gibi yürütme erki için de iktidarı tek başına kullanma ve mutlak iktidara yönelme riski her zaman vardır. Bu riski bertaraf etmek üzere erklerin sahip oldukları gücün ve yetkilerin birbirine karşı sınırlandırılması öngörülmüştür.

Yarg1 erkine gelince, Montesquieu yarg1 gücünün yasama gücüyle birleşmesi, ya da yürütme gücüyle birleşmesi durumunda işlevini kaybedeceğini savunmuştur. Adalet dağıtmakla yükümlü bulunan yargı erkinin gerek yasama gerekse yürütme erkiyle aynı elde birleşmesi durumunda birey özgürlükle-

\footnotetext{
65 Doehring, s. 152.

${ }^{66}$ Montesquieu, s. 205-206.

67 Montesquieu, s. 206.
} 
rinin ortadan kalkacağını tespit etmiştir. Yasama, yürütme ve yargı erklerinin aynı kişi ya da organ tarafından kullanılması durumunu despotluk olarak tanımlamıştır. ${ }^{68}$ Diğer erklerden farklı olarak yargı erki doğası gereği yasama ile yürütme erkleri arasındaki ilişki formunun dışında değerlendirilmektedir. Yukarıda belirtildiği gibi yasamanın da yürütmenin de yargıyla birleşmesi kabul edilemez. Ancak yürütme bakımından kabul edilen yargıya istisnasız müdahale yasağının, yasamanın müdahale yasağıyla aynı şekilde işlemediğini belirmek gerekir.

Yasamanın yargıya müdahale yasağının, yürütmenin yargıya müdahale yasağından farklılaştığı belirtilmişti. Bunun nedeni yasamanın yargıya müdahale etmesine ilişkin yasağın üç istisnası bulunduğunun kabul edilmesidir. Bunlardan birincisi, seçkinlerin yargılanmasının halk tarafından seçilen yargıçlarca yapılmasının sakıncalı bulunması durumudur. Özgür bir devlette her bir yurttaşın eşitleri tarafından yargılanması uygundur. Buna göre soyluların olağan mahkemeler tarafından değil, yasama organının soylulardan oluşan bölümü tarafından yargılanması doğru olacaktır. Bu nedenle Lordlar Kamarası soyluları her konuda yargılayabilen mahkeme olarak işlev görecektir. ${ }^{69}$

İkinci istisna durumu, yasaların çok ağır ve çok katı bir şekilde düzenlenmiş olmaları halinde söz konudur. Çok ağır yasalar uyarınca yargılanıp da aleyhinde cezaya hükmedilmiş olan kişilerin affedilmesi ya da cezalarının indirilmesi mümkündür. Böyle bir durumda yine Lordlar Kamarası devreye girerek mahkeme işlevi görecektir. Mahkeme olarak çalışacak olan soylular meclisi, ilgili yasayı yasa lehinde yumuşatmak görevini yerine getirecektir. ${ }^{70}$

Yargı ile yasama arasındaki ilişkide yer alan ve yasama erkinin yargıya müdahalesinin meşru kabul edildiği üçüncü ve son istisnai durum, kamu hizmetinde çalışan görevlilerin yargılanmasını ilgilendirmektedir. Kamu görevlilerinin de halkın haklarını çiğnemesi ve suç işlemesi mümkündür. Böyle bir durumda olağan mahkemeler, kamu görevlilerini yargılamayı ve onları cezalandırmayı istemeyebilirler. Montesquieu, siyasal davalar olarak adland1rılabilecek bu nitelikteki yargılamaların genel meclis tarafından gerçekleşti-

\footnotetext{
68 Montesquieu, s. 199-200.

69 Montesquieu, s. 207.

70 Montesquieu, s. 201, s. 207.
} 
rilmesini uygun bulmamıştır. Davacı konumundaki halkı temsil eden halk meclisi savcılık rolünü, sanıkla eşit olan soylular meclisinin mensupları yargıçlık rolünü üstleneceklerdir. ${ }^{71} \mathrm{Bu}$ durum, İngiliz hukukunda bakanların Avam Kamarası tarafından suçlanıp Lordlar Kamarası tarafından yargılanmasını öngören impeachment müessesesini akla getirmektedir. ${ }^{72}$ Söz konusu benzerlik, daha önce de örneklediğimiz gibi Montesquieu'nun düşünceleri ile İngiliz anayasal hukuku arasındaki etkileşimi ortaya koymaktadır.

\section{KUVVETLER AYRILIĞINA MUHALİF GÖRÜŞLER}

Montesquieu ile aynı dönemde yaşayan, ancak güçler ayrılığı düşüncesiyle farklılaşan düşünürlerden biri Rousseau'dur. Temel olarak Rousseau da Locke gibi siyasal özgürlüğün, iktidarı sınırlandıracak kuralların varlığına bağlı olduğunu kabul etmekte, siyasal özgürlük ile yasalar arasındaki ilişkiyi dile getirmektedir. ${ }^{73}$ Bununla birlikte kuvvetler ayrılığı düşüncesine muhalefet eden Rousseau, “Toplum Sözleşmesi” adlı eserinde egemenliğin bölünmezliği düşüncesini esas almıştır. Aynı dönemde kuvvetler ayrılığı rejiminin uygulanabilir olmadığını değerlendiren pek çok hukukçu da bu sisteme muhalefet etmişlerdir. Özellikle Almanya'da kuvvetler ayrılı̆̆ına muhalif görüşlerin geniş destek gördüğü söylenebilir. Laband, Jellinek. Mohl, Stein, Meyer, Wilson, Duguit, Moreau, Cahen, Eugène d'Eichtal, Seignobos, Orlando, Capitant, Eisenman, Lureau, ve Onar gibi hukukçular Rousseau gibi egemenliğin parçalanamayacağını savunmuşlardır. ${ }^{74}$

Kuvvetler ayrılığına muhalif görüşler içinde ilk ortaya atılanı Rousseau'nun görüşleri olmuştur. Rousseau, Locke ve Montesquieu gibi doğal yaşam ve doğal hukuk anlayışını temel aldığı halde, siyasal erklere ilişkin olarak onların aksi yönde görüşler geliştirmiştir. Rousseau'ya göre egemenlik, başkasına devredilemeyeceği gibi bölünmemelidir de. Rousseau, ne şekilde olursa olsun kuvvetlerin ayrılmasını öngören yaklaşımın yanlış olduğunu savunmuş-

\footnotetext{
71 Montesquieu, s. 207.

72 A ğaoğulları / Zabçı / Ergün, s. 429.
}

73 Sartori, Giovanni (1996) Demokrasi Teorisine Geri Dönüş, Karamustafaoğlu, Tunçer / Turhan, Mehmet (Çev.), Ankara, Yetkin Yayınları, s. 332.

74 Okandan, Recai Galip (1936) 'Âmme Hukukunda Kuvvetler Bölümü Meselesi', İstanbul Üniversitesi Hukuk Fakültesi Mecmuas1, C: 2, ss. 502-523, s. 510. 
tur. Halkın egemenliği bölünmez ve devredilmez olarak nitelendiğinde, iktidarı kullanan organların da ayrılması kabul edilemez. ${ }^{75}$ Egemenlik farklı organların bünyesine katılmış çeşitli unsurlara bölünemez, iki ya da daha fazla organ arasında bölünemez. ${ }^{76}$ Egemenliğin parçaları sanılan yetkiler bir bütündür ve her zaman bir yüksek iradenin varlığını gerektirmektedir. Çeşitli ayrımlara başvurularak bölünmek istenen yetkiler aslında tekil yüksek iradenin uygulanmasını sağlamaktadır. ${ }^{77}$

Rousseau'dan sonra Doyen Duguit, kuvvetler ayrılığı ilkesini kuramsal ve yapay olarak nitelendirmiş ve sosyal gerçeklikle bağdaşmadığını ileri sürmüştür. ${ }^{78}$ Moreau ise kuvvetler ayrılı̆̆ 1 ilkesini karanlık ve hayalci bir görüş olarak değerlendirmiş ve tatbikinin mümkün olmadığını savunmuştur. Orlando, devletin teşkilat yapısı ile kuvvetler ayrılığı ilkesinin bağdaşamayacağını ifade etmiştir. ${ }^{79}$

Locke ve Montesquieu kamusal yararı gerçekleştirme amacından sapma eğiliminden dolayı iktidarın gücünün sınırlanması ihtiyacından hareketle erkler ayrımını savunmuşlardır. Rousseau ise genel iradenin her zaman doğru olduğunu ve kamusal yararı gerçekleştirmeye yönelik olduğunu kabul etmiştir. ${ }^{80} \mathrm{Bu}$ noktada Locke'un yasama erkini diğer erklerden üstün olarak tasarladığını vurgulamak gerekir. Locke'a göre yasama erki, devlete biçimini, hayatını ve birliğini verdiği için yürütmeden üstündür. Yasama erkini diğer erklerden üstün olarak değerlendirmeleri bakımından iki düşünürün yaklaşımları arasında müşterek bir boyut bulunduğu söylenebilir.

Locke'ta ve Montesquieu'da halkın üstün otoritesi, yönetimin yasama, yürütme ve yargı organlarına devredilirken; Rousseau ve diğer muhaliflerin düşüncesinde egemenliğin bölünemezliği ve ayrıştırılamazlığı vasfı, otoritenin yönetim organları arasında bölüşülmesine engel olarak görülmüştür. Locke

75 Rousseau, Jean Jacques (1994) Toplum Sözleşmesi, Günyol, Vedat (Çev.), 6. Bası, Adam Yayınlar1, s. 36-37.

76 Duguit, Leon (2005) 'Egemenlik ve Özgürlük', Akal, Cemal Bali (Der.), Devlet Kuramı, 2. Bası, Ankara, Dost Yayınevi, ss. 379-400, s. 386.

77 Rousseau, s. 68.

78 Okandan, s. 510.

79 Okandan, s. 511.

80 Rousseau, s. 69. 
tarafından açılan yolda Montesquieu tarafından geliştirilen kuvvetler ayrılığı anlayışının, kendi dönemlerinde, erkler arasında fren ve denge mekanizması tesis ederek etkin şekilde uygulanmasının, çeşitli nedenlerle mümkün olmadiğını vurgulamak gerekir. Onların geliştirdiği düşünceler daha çok on sekizinci yüzyıl burjuvazisi tarafından mutlak monarşiye karşı kullanılmıştır. Burjuva devrimleri başarıya ulaştığında, yasama, yürütme ve yargı şeklindeki üçlü güçler ayrılı̆̆ 1 prensibi, Amerikan ve Fransız devletlerinin anayasalarına geçmiştir. ${ }^{81}$ Günümüzde ise güçler ayrılığı, çağdaş anayasaların temel prensibi olarak yer edinmiş, demokratik yönetimlerin vazgeçilmez unsuru olarak kabul edilmiştir.

\section{SONUÇ}

Kuvvetler ayrıllğı düşüncesi İlk Çağ’ dan itibaren temelleri atılmaya başlanan bir yaklaşımın ürünü olmuştur. İdeal yönetim anlayışılla yola çıkan ve en iyi hükümet fikrini arayan Aristoteles, devletin faaliyetlerini üçe ayırarak her faaliyetin bir organa verilmesi gerektiği düşüncesini ilk kez ortaya atmıştır. Böylece üçlü görev paylaşımı düşüncesi tamamıyla işlevsel bir ayrım olarak doğmuştur. Polybios döneminde ise, yönetimin bozulmasının önüne geçmek için siyasal gücün, birbirini denetleyebilecek çeşitli kurumlar arasında dağıtılması düşüncesi savunulmuştur.

Modern anlamıyla kuvvetler ayrılığı anlayışının temellerini ise John Locke ve Baron de Montesquieu'nun çalışmaları oluşturmuştur. Locke, yasama ve yürütmenin yanındaki üçüncü erki, federatif erk olarak tasarlamış ve yasamanın üstünlüğü esasını savunmuştur. Locke, Montesquieu'dan farklı olarak erklerin sinırlandırılmasından ziyade üstün olan yasama iktidarının sınırlandırılması gereği üzerinde durmuştur. Montesquieu ise erkleri yasama, yürütme ve yargı erkleri olarak tasarlamış ve birbirini frenleyip dengeledikleri bir sistem içinde ele almıştır. Böylece modern anlamdaki üçlü kuvvetler ayrılı$\breve{g} 1$ anlayışını Montesquieu, hem betimleyici hem kuramsal bir yaklaşımla geliştirmiştir. Erkler arasındaki ilişkilere odaklanan Montesquieu, yasama erki için olduğu gibi yürütme erki için de iktidarı tek başına kullanma ve mutlak iktidara yönelme riskinin bulunduğunu; bu riski bertaraf etmek üzere erklerin

81 Şenel, s. 386-387. 
sahip oldukları gücün ve yetkilerin birbirine karşı sınırlandırılmasına ilişkin mekanizmalara başvurulmasını savunmuştur.

Locke'un kuvvetler ayrılığı teorisi, iktidarın sınırlılığı ve temel hakların iktidar tarafından kaldırılamayacağı yönündeki boyutuyla Amerikan Bağımsızlık Bildirgesinde ve Amerikan Anayasasında açık şekilde etki yapmıştır. İngiltere'deki düşünsel gelenek üzerinde ise daha çok yasamanın (parlamentonun) üstünlüğü teorisiyle iz bırakmıştır. ${ }^{82}$ Montesquieu'nun halk otoritesinin, yönetimin yasama, yürütme ve yargı organlarına devredilmesini öngören ve doktrin olarak gelişen güçler ayrılı̆̆ düşüncesi de devrim dönemine güçlü etkiler yapmıştır. Fransız İnsan ve Yurttaş Hakları Bildirgesinde "Halkların emniyet altına alınmadığı ve güçler ayrımının sağlanmadığı bir toplumun meşruiyeti yoktur" hükmü yer bulmuştur. Bu dönemde siyasal erklerin birbirinden ayrılması ve karşılıklı birbirlerini sınırlandırması anlayışı, siyasal gücün hükümdarda toplanması anlayışına tercih edilmiştir. ${ }^{83}$

Bununla birlikte Fransız Devriminin yapıcıları, Montesquieu'nun kuvvetler ayrılığına ilişkin pratik anlayışını efsaneleştirme yoluna gitmeyi tercih etmişlerdir. Devrimden sonra anayasal hareketlerin esin kaynağını oluşturan, kuvvetlerin birbirinden bağımsız olarak ayrı ayrı kullanılması anlayışı, İhtilalin metafizikleştirdiği, hatta tabulaştırdığı bir siyasal felsefenin ürünü haline gelmiştir. ${ }^{84} 1789$ tarihli Fransız İnsan ve Yurttaş Hakları Bildirisinin 16. maddesi kuvvetler ayrılığının anayasal devlet için zorunlu bir unsur olduğunu belirtmekteydi. Ancak İhtilalin dogmatizmi, kuvvetler arasında herhangi bir ilişki ve orantı mekanizması kurulmasının önüne geçmeye başlamıştır. Bunun sonucunda bir zamanlar Avrupa'da örnek alınan Fransız yönetim sistemi devrim sonrası yıllarda ününü yitirme yoluna girmiştir. Rousseau'nun mutlak egemenlik anlayışı, genel iradenin yanılmazlığı ile egemenin gücün sınırlılığına ilişkin çelişik görüşleri, Fransız Devrimini ve sonraki dönemlerin siyaset bilimcilerini bu doğrultuda etkilemiştir. ${ }^{85}$

82 A ğaoğulları / Zabçı / Ergün, s. 230.

83 Poggi, Gianfranco (2014) Devlet: Doğası, Gelişimi ve Geleceği, Babacan, Aysun (Çev.) 4. Bası, İstanbul, Bilgi Üniversitesi Yayınları, s. 76-77.

84 Tunaya, s. 390.

85 Ağaoğulları, Mehmet Ali (2010) Ulus - Devlet ya da Halkın Egemenliği, 2. Bası, Ankara, İmge Kitabevi, s. 104-106. 
Locke gibi Rousseau da doğal yaşam ve doğal hukuk anlayışını temel aldığ 1 halde siyasal erklere ilişkin olarak Locke ve Montesquieu'nun ulaştığı düşüncelerin tam tersi görüşler geliştirmiştir. Halkın egemenliği bölünmez ve devredilmez olarak nitelendiğinde, iktidarı kullanan organların da ayrılması kabul edilemez. Locke'ta ve Montesquieu'da halkın üstün otoritesi, yönetimin yasama, yürütme ve yargı organlarına devredilirken; Rousseau'nun bölünemez ve ayrıştırılamaz egemenlik kavramı, otoritenin yönetim organları arasında bölüşülmesine engel olarak görülmüştür. Locke tarafından açılan yolda Montesquieu'nun geliştirdiği kuvvetler ayrılığı anlayışının erkler arasında fren ve denge mekanizması tesis ederek uygulanması, devrim koşulları ve genel irade teorisinin sonucu olan yasamanın üstünlügü anlayışı nedeniyle mümkün olmamıştır.

Devrimler döneminde yasamanın üstünlüğü düşüncesi, kuvvetler ayr1lığı ilkesinin fren ve denge mekanizmalarıyla uygulanmasının önüne geçmiştir. Rousseaucu düşünce ekseninde ulusal egemenliğin bir tür dogma olarak görülmesi, egemenliğin tanrısal bir yetkilendirme olarak temellendirilmesi, bir dönem boyunca çoğunluk tahakkümüne dayalı iktidar anlayışını hâkim kılmıştır. ${ }^{86}$ Çoğunlukçu genel irade anlayışının etkileri, Kıta Avrupası'nda yasamaya yönelik anayasal yargı denetiminin gelişmesini geciktirmiş olsa da; çă̆daş anayasal sistemlerde üçlü erkler ayrımı demokrasinin vazgeçilmez unsuru olarak yer bulmuştur. Locke'un ve Montesquieu'nun çalışmalarıyla on yedinci-on sekizinci yüzyıllarda geliştirilen kuvvetler ayrılığı ilkesinin çağdaş demokrasi anlayışı bakımından taşıdığı önem tartışmasızdır. Günümüzde kuvvetler ayrılığına dayanmayan bir yönetimin, demokratik olma vasfina sahip olamayacağı anlayışı hâkimdir. Dolayısıyla kuvvetler ayrılığı prensibi, anayasacılık ve demokrasi tarihinin en önemli kazanımları arasında yer almaktadır.

86 Duguit, s. 394-395. 


\section{KAYNAKÇA}

A ğaoğulları, Mehmet Ali (Şubat 2002) Kral Devletinden İmparatorluğa, 3. Bası, Ankara-İstanbul, İmge Kitabevi.

Ağaoğulları, Mehmet Ali / Çulha Zabçı, Filiz / Ergün, Reyda (Eylül 2009) Kral Devletten Ulus Devlete, 2. Bası, Ankara, İmge Kitabevi.

A ğaoğulları, Mehmet Ali (Ekim 2010) Ulus- Devlet ya da Halkın Egemenliği, 2. Bası, Ankara, İmge Kitabevi.

Akad, Mehmed / Dinçkol, Bihterin Vural / Bulut, Nihat (2014) Genel Kamu Hukuku, 10. Bası, İstanbul, Der Yayınları.

Akgül, Mehmet Emin 'Kuvvetler Ayrıllğı İlkesini Dönüşümü ve Günümüz Demokratik Rejimlerindeki Anlamı', Ankara Barosu Dergisi, S: 4, Y: 2010, ss. 79-101.

Akın, İlhan F. (Ekim 1993) Kamu Hukuku, 7. Bası, İstanbul, Beta Yayinevi.

Akipek, İlhan 'Kuvvetler Ayrilığı Nazariyesinin Doğmasında Âmil Olan Fikirler', Ankara Üniversitesi Hukuk Fakültesi Dergisi, C: 9, S: 1, Y: 1952, ss. 167-182.

Aristoteles (2005) Politika, Tunçay, Mete (Çev.), İstanbul, Remzi Kitabevi.

Doehring, Karl (2002) Genel Devlet Kuramı (Genel Kamu Hukuku), Mumcu, Ahmet (Çev.), İstanbul, İnkılap Kitabevi.

Duguit, Leon (2005) 'Egemenlik ve Özgürlük', Akal, Cemal Bali (Der.), Devlet Kuram1, 2. Bası, Ankara, Dost Yayınevi, ss. 379-400.

Flaherty, Martin S. 'The Most Dangerous Branch Abroad', Harward Journal of Law and Public Policy, C: 30, S: 1, Sonbahar 2006, ss. 153-171.

Göze, Ayferi (Ağustos 2016) Siyasal Düşünceler ve Yönetimler, 16. Bası, İstanbul, Beta Yayınları.

Jenkins, David 'The Lockean Constitution: Separation of Powers and the Limits of Prerogative', Mc Gill Law Journal, C: 56, S: 3, Nisan 2011, ss. 543-589. 
Locke, John (1940) Of Civil Government, New York, J. M. Dentand Sons Ltd. London / E. P. Duttonand Co. Inc.

Locke, John (1952) The Second Treatise of Government, New York, The Liberal Arts Press.

Montesquieu (2017) Yasaların Ruhu Üzerine, Günen, Berna (Çev.), 2. Bası, İstanbul, İş Bankası Kültür Yayınları.

Okandan, Recai Galip 'Âmme Hukukunda Kuvvetler Bölümü Meselesi', İstanbul Üniversitesi Hukuk Fakültesi Mecmuası, C: 2, Y: 1936, ss. 502523.

Poggi, Gianfranco (2014) Devlet: Doğası, Gelişimi ve Geleceği, Babacan, Aysun (Çev.) 4. Bası, İstanbul, Bilgi Üniversitesi Yayınları.

Rousseau, Jean Jacques (1994) Toplum Sözleşmesi, Günyol, Vedat (Çev.), 6. Bası, Adam Yayınları.

Ratnapala, Suri 'John Locke's Doctrine of the Separation of Powers: a Re-Evaluation', The American Journal of Jurisprudence, C: 38, S:1, Ocak 1993, ss. 189-220.

Săraru, Cătălin-Silviu "The State and the Separation of Powers", Juridical Tribune, C: 5, S: 2, Aralık 2015, ss. 274-280.

Sartori, Giovanni (1996) Demokrasi Teorisine Geri Dönüş, Karamustafaoğlu, Tunçer / Turhan, Mehmet (Çev.), Ankara, Yetkin Yayınları.

Schulze, Hagen (2005) Avrupa'da Ulus ve Devlet, Binder, Timuçin (Çev.), İstanbul, Literatür Yayınları.

Şenel, Alaeddin (1995) Siyasal Düşünceler Tarihi, 4. Kısaltılmış Bası, Ankara, Bilim ve Sanat Yayınları.

Touchard, Jean (2015) Siyasal Düşünceler Tarihi, Yerguz, İsmail (Çev.), İstanbul, Islık Yayınları.

Tunaya, Tarık Zafer (1980) Siyasal Kurumlar ve Anayasa Hukuku, İstanbul Üniversitesi Hukuk Fakültesi Yayınları, 4. Bası, İstanbul, Fakülteler Matbaasi.

Uygun, Oktay (Ocak 2017) Devlet Teorisi, 3. Bası, İstanbul, On İki Levha Yayınları.

Vile, M.J.C. (1998) Constitutionalism and the Separation of Powers, 2. Bas1, Indianapolis, Liberty Fund. 